\title{
Protein C Deficiency in a Family with Thromboembolism and Identified Gene Mutations
}

\author{
Sakuo Hoshi ${ }^{1,2}$, Minako Hijikata ${ }^{3}$, Yuuki Togashi ${ }^{1}$, Tetsuji Aoyagi ${ }^{1}$, Chiyoko Kono ${ }^{1}$, \\ Yoshihito Yamada ${ }^{1}$, Hiroko Amano ${ }^{1}$, Naoto Keicho ${ }^{3}$ and Tetsuo Yamaguchi ${ }^{1}$
}

\begin{abstract}
Protein $\mathrm{C}$ is the central component of the major anti-thrombotic regulatory system, and individuals with hereditary protein $\mathrm{C}$ deficiency tend to have an increased risk of thromboembolism. During the last several years, mutations causing protein $\mathrm{C}$ deficiency have been identified. In the present study, we report familial cases with three nucleotide substitutions: One is a missense mutation Arg169Trp, which was previously reported. The other two are C-154T promoter polymorphism (rs1799808 on dbSNP database), the function of which is unkonwn and Ser99Ser synonymous polymorphism (rs5936). All three mutations were found in a 24-year-old patient with pulmonary thromboembolism and his 54-year-old father who also had pulmonary thromboembolism. C-154T promoter polymorphism (rs1799808 on dbSNP database) and Ser99Ser synonymous polymorphism (rs5936) were found in the patient's mother.
\end{abstract}

Key words: protein $\mathrm{C}$ deficiency, missense mutation, pulmonary thromboembolism, promoter polymorphism, hotspot

(DOI: 10.2169/internalmedicine.46.6277)

\section{Introduction}

Protein $\mathrm{C}$ is a vitamin K-dependent zymogen of serine protease that inhibits blood coagulation by the proteolytic inactivation of factors Va and VIIIa (1). Individuals affected with protein $\mathrm{C}$ deficiency are at risk for arterial or venous thrombosis (2). The diagnosis of protein $\mathrm{C}$ deficiency has been based on the laboratory assay of plasma protein $\mathrm{C}$ antigen and activity levels (3). Protein $\mathrm{C}$ deficiency has phenotypically been classified into two types. Type I deficiency, the most common, is characterized by the parallel reduction of protein $\mathrm{C}$ activity and antigen levels due to the reduced synthesis or stability of normally functioning molecules. In type II deficiency, protein $\mathrm{C}$ activity is reduced to a greater extent than the antigen due to the synthesis of an abnormal protein C molecule exhibiting a reduced specific activity (4).

Protein $\mathrm{C}$ deficiencies are inherited as an autosomal dominant trait. The protein $\mathrm{C}$ gene resides on chromosome 2 and comprises 9 exons (5). Researchers have found over 160 different mutations of the protein $\mathrm{C}$ gene that lead to the ab- sence, or a defective form, of protein C (6). We found three nucleotide substitutions in the patient and his father. The result of protein $\mathrm{C}$ activity and antigen levels suggested that the patient and his father might have type II protein $\mathrm{C}$ deficiency, which is rare.

The patient's father had been given a diagnosis of pulmonary thromboembolism three years prior to the patient's admission. If the patient had had a chance to examine his protein $\mathrm{C}$ activity and antigen, lifestyle-related counseling might have been provided to him. Therefore, we report this case to enhance patient care and provide a review of the literature.

\section{Case Report}

A 24-year-old railway worker was admitted to our hospital because of dyspnea on exercise, which had gradually worsened in one month. He had experienced left leg pain three months prior to admission without any cause, such as a predominantly seated position for long time.

The patient had been drinking 0.5 liter of beer per day

\footnotetext{
${ }^{1}$ Respiratory Medicine, JR Tokyo General Hospital, Tokyo, ${ }^{2}$ Allergy and Respiratory Medicine, Doai Memorial Hospital, Tokyo and ${ }^{3}$ Research Institute, Respiratory Diseases, International Medical Center of Japan, Tokyo

Received for publication October 1, 2006; Accepted for publication March 21, 2007

Correspondence to Dr. Sakuo Hoshi, sakuchin@sannet.ne.jp
} 


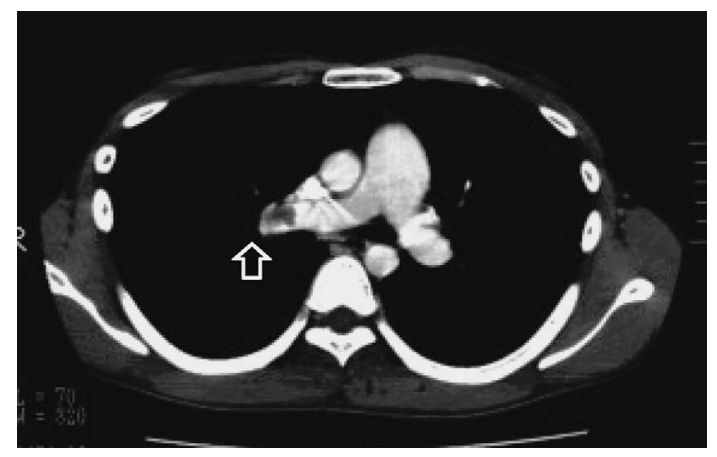

Figure 1. Computed tomography of the chest showing thrombosis of the right pulmonary artery (arrow).

Table 1. Laboratory Data of the Patient on Admission

\begin{tabular}{|c|c|c|c|c|}
\hline \multicolumn{2}{|c|}{ Hematology } & $\mathrm{Na}$ & \multicolumn{2}{|c|}{$142 \mathrm{mEq} / 1$} \\
\hline WBC & $13,200 / \mu 1$ & $\mathrm{~K}$ & \multicolumn{2}{|c|}{$3.9 \mathrm{mEq} / 1$} \\
\hline $\mathrm{RBC}$ & $526 \times 10^{4} / \mu 1$ & $\mathrm{Cl}$ & \multicolumn{2}{|c|}{$104 \mathrm{mEq} / \mathrm{l}$} \\
\hline $\mathrm{Hb}$ & $16.3 \mathrm{~g} / \mathrm{dl}$ & \multicolumn{3}{|c|}{ Immunology } \\
\hline $\mathrm{Ht}$ & $49.9 \%$ & CRP & \multicolumn{2}{|c|}{$0.3 \mathrm{mg} / \mathrm{dl}$} \\
\hline PLT & $45.6 \times 10^{4} / \mu 1$ & ANA & & $(-)$ \\
\hline \multicolumn{2}{|c|}{ Blood chemistry } & \multicolumn{3}{|c|}{ Anticardiolipin antibody $(-)$} \\
\hline $\mathrm{TP}$ & $7.1 \mathrm{~g} / \mathrm{dl}$ & Lupus antic & ggulant & $(-)$ \\
\hline $\mathrm{Alb}$ & $4.7 \mathrm{~g} / \mathrm{dl}$ & \multicolumn{3}{|c|}{ Coagulation test } \\
\hline BUN & $13.4 \mathrm{mg} / \mathrm{dl}$ & PT & & $81 \%$ \\
\hline Creat & $0.9 \mathrm{mg} / \mathrm{dl}$ & APTT & & $30 \mathrm{sec}$ \\
\hline $\mathrm{T}-\mathrm{Bil}$ & $0.7 \mathrm{mg} / \mathrm{dl}$ & Fibrinogen & $252 n$ & $\mathrm{ng} / \mathrm{dl}$ \\
\hline AST & $20 \mathrm{IU} / 1$ & AT- III & 29.4 & $\mathrm{mg} / \mathrm{dl}$ \\
\hline ALT & $26 \mathrm{IU} / 1$ & FDP & 7.1 & $\mathrm{~g} / \mathrm{ml}$ \\
\hline LDH & $471 \mathrm{IU} / 1$ & D-dimer & $4.8 \mu$ & $\mathrm{g} / \mathrm{ml}$ \\
\hline
\end{tabular}

and smoking 20 cigarettes per day for over the past 4 years. His height was $177 \mathrm{~cm}$ and his weight was $56 \mathrm{~kg}$. He was not febrile $\left(36.8^{\circ} \mathrm{C}\right)$, his pulse rate was $87 / \mathrm{min}$, and his blood pressure was $118 / 76 \mathrm{mmHg}$. There were no heart murmurs and his respiratory sounds were normal. His electrocardiogram showed terminal $\mathrm{T}$ inversions in leads II, III, ${ }_{a} V_{f}$ and $V_{1-4}$. Computed tomography of the chest showed thrombosis of the right pulmonary artery (Fig. 1). Laboratory studies prior to heparin therapy demonstrated high lev-

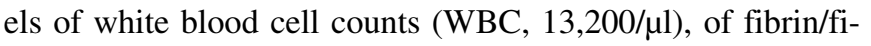
brinogen degradation products (FDP, $7.1 \mu \mathrm{g} / \mathrm{ml}$ ), and Ddimer $(4.8 \mu \mathrm{g} / \mathrm{ml})$. His prothrombin time (PT) was $81 \%$ and activated partial thromboplastin time (APTT) was $30 \mathrm{sec}-$ onds (normal range: 25.0-38.0 seconds). Only D-dimer was slightly elevated. Protein $\mathrm{C}$ antigen and activity were $68 \%$ (normal range: $70-150 \%$ ) and $43 \%$ (normal range: 64$146 \%$ ), and corresponding values for protein $S$ were $72 \%$ (normal range: 65-135\%) and $82 \%$ (normal range: 60$150 \%$ ), respectively. Protein C activity and Protein S activity were measured by the APTT clotting time method. Protein $\mathrm{C}$ antigen was measured by latex photometric immuno-
Table 2. Laboratory Data of the Patient's Father on Admission

\begin{tabular}{|c|c|c|c|}
\hline \multicolumn{2}{|c|}{ Hematology } & $\mathrm{Na}$ & $138 \mathrm{mEq} / 1$ \\
\hline WBC & $13,200 / \mu 1$ & $\mathrm{~K}$ & $3.6 \mathrm{mEq} / 1$ \\
\hline $\mathrm{RBC}$ & $380 \times 10^{4} / \mu 1$ & $\mathrm{Cl}$ & $104 \mathrm{mEq} / 1$ \\
\hline $\mathrm{Hb}$ & $12.4 \mathrm{~g} / \mathrm{dl}$ & \multicolumn{2}{|c|}{ Immunology } \\
\hline $\mathrm{Ht}$ & $35.8 \%$ & CRP & $16.1 \mathrm{mg} / \mathrm{dl}$ \\
\hline PLT & $45.6 \times 10^{4} / \mu 1$ & ANA & $(-)$ \\
\hline \multicolumn{2}{|c|}{ Blood chemistry } & \multicolumn{2}{|c|}{ Anticardiolipin antibody $(-)$} \\
\hline $\mathrm{TP}$ & $5.2 \mathrm{~g} / \mathrm{dl}$ & \multicolumn{2}{|c|}{ Coagulation test } \\
\hline $\mathrm{Alb}$ & $2.5 \mathrm{~g} / \mathrm{dl}$ & PT & $51 \%$ \\
\hline BUN & $7.8 \mathrm{mg} / \mathrm{dl}$ & APTT & $111 \mathrm{sec}$ \\
\hline Creat & $0.7 \mathrm{mg} / \mathrm{dl}$ & Fibrinogen & $641 \mathrm{mg} / \mathrm{dl}$ \\
\hline $\mathrm{T}-\mathrm{Bil}$ & $0.7 \mathrm{mg} / \mathrm{dl}$ & AT- III & $19.8 \mathrm{mg} / \mathrm{dl}$ \\
\hline AST & $59 \mathrm{IU} / 1$ & FDP & $12.0 \mu \mathrm{g} / \mathrm{ml}$ \\
\hline ALT & $69 \mathrm{IU} / 1$ & D-dimer & $3.5 \mu \mathrm{g} / \mathrm{ml}$ \\
\hline LDH & $489 \mathrm{IU} / 1$ & & \\
\hline
\end{tabular}

assay. Protein S antigen was measured by emzyme immunoassay $(7,8)$. Lupus anticoagulant was negative (Tables 1, 3).

Initial intravenous administration of heparin $(15,000 \mathrm{U} /$ day) and urokinase (480,000 U/day for 2 days, then 120,000 U/day for 5 days) was followed by warfarin potassium combined with heparin. Then an oral anticoagulant (warfarin potassium) was continued to keep PT INR within the range from 2 to 3. Dyspnea on exercise improved. Computed tomography of the chest performed on day 32 showed no detectable thrombosis of the right pulmonary artery (data not shown).

The patient's father had been given a diagnosis of protein C deficiency accompanied by pulmonary thromboembolism at our hospital three years previously, who suffered sudden onset of dyspnea also without any cause. Protein $\mathrm{C}$ antigen and activity were 56\% (normal range: $70-150 \%$ ) and $28 \%$ (normal range: $64-146 \%$ ), and corresponding values for protein S were $120 \%$ (normal range: $65-135 \%$ ) and $120 \%$ (normal range: 60-150\%), respectively (Tables 2, 3). His father also had received anticoagulant therapy.

The patient's father had 4 sisters (Fig. 2). None of them had any episode of pulmonary thromboembolism. The patient's sister had normal protein $\mathrm{C}$ and $\mathrm{S}$ antigen levels and activity (Table 3 ). The patient's mother also had normal protein $\mathrm{C}$ and $\mathrm{S}$ antigen levels and activity (Table 3 ).

Gene analysis was performed in the patient, his father, his mother and sister after written informed consent was obtained from all four subjects.

This genetic analysis was approved by our institutional ethical committee and genetic counseling was appropriately provided to the family. Isolation of genomic DNA from whole blood was followed by PCR/direct sequencing analysis of the protein $\mathrm{C}$ gene. DNA sequence was performed 
Table 3. Phenotypic and Genotypic Data From the Patient and Family Members

\begin{tabular}{|c|c|c|c|c|c|c|c|}
\hline \multirow{2}{*}{$\begin{array}{l}\text { Family } \\
\text { member }\end{array}$} & \multirow{2}{*}{$\begin{array}{l}\text { PC activity (\%) } \\
\text { (NR 64-146\%) }\end{array}$} & \multirow{2}{*}{$\begin{array}{l}\text { PC antigen (\%) } \\
\text { (NR 70-150\%) }\end{array}$} & \multirow{2}{*}{$\begin{array}{l}\text { PS activity (\%) } \\
(\text { NR } 60-150 \%)\end{array}$} & \multirow{2}{*}{$\begin{array}{l}\text { PS antigen (\%) } \\
(\text { NR 65-135\%) }\end{array}$} & \multicolumn{2}{|c|}{ PROC mutation } & \multirow[b]{2}{*}{$\mathrm{C}-154 \mathrm{~T}$} \\
\hline & & & & & $\begin{array}{c}\text { C6218T } \\
\text { (Arg169Trp) }\end{array}$ & $\begin{array}{r}\text { G3342T } \\
\text { (Ser99Ser) }\end{array}$ & \\
\hline II -5 & 28 & 56 & 120 & 120 & + & + & + \\
\hline$\Pi 1-6$ & 118 & 144 & 71 & 112 & - & + & + \\
\hline III-1 & 77 & 92 & N.T. & N.T. & - & - & - \\
\hline III-2 & 43 & 68 & 82 & 72 & + & + & + \\
\hline
\end{tabular}

NR: normal range, N.T.: not tested

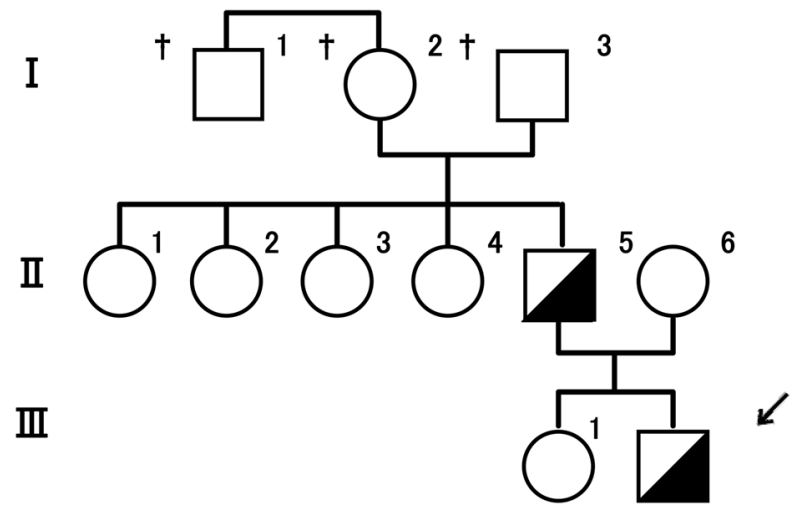

Figure 2. The pedigree of the family. The patient is indicated by an arrow. $\dagger$ : deceased. $\bigcirc$ and $\square$ : unaffected females and males. Half-solid symbols represent affected females and males with abnormal protein $\mathrm{C}$ gene and heterozygosity for protein $\mathbf{C}$ deficiency.

both $5^{\prime} \rightarrow 3^{\prime}$ and $3^{\prime} \rightarrow 5^{\prime}$ direction and we confirmed the entire matching of the DNA sequence. The sequence analysis of the patient's protein $\mathrm{C}$ gene and his father's protein $\mathrm{C}$ gene indicated a heterozygous transition of $\mathrm{C}$ to $\mathrm{T}$ at nucleotide 6,218 in exon7, which resulted in the substitution of the arginine for the tryptophan at amino acid residue 169 (Fig. 3). This mutation was not found in the patient's mother or the patient's sister (Fig. 3). Sequence analysis of the protein $\mathrm{C}$ gene indicated $\mathrm{C}-154 \mathrm{~T}$ promoter polymorphism (rs1799808 on dbSNP database) and Ser99Ser synonymous polymorphism (rs5936) in the patient, his father and mother (Table 3).

\section{Discussion}

Griffin et al described familial thrombosis in association with protein C deficiency in 1981 (9). They emphasized the clinical importance of protein $\mathrm{C}$ in controlling the hemostatic system. Since that time, numerous cases of hereditary protein $\mathrm{C}$ deficiency have provided convincing evidence of the fact that individuals with protein $\mathrm{C}$ deficiency tend to have an increased risk of thromboembolism (10).

The prevalence of heterozygous protein $\mathrm{C}$ deficiency is estimated to be one in 200 to 300 of the general population (11). However, only a minor subgroup of these subjects develop thrombotic complications at a young age, whereas most others remain asymptomatic throughout their lives (12). Estimates of the prevalence of clinically symptomatic deficiencies of protein $\mathrm{C}$ in the general population lie between $1: 16,000$ and $1: 36,000$ (13). This finding suggests that the severity of clinical manifestations may be related to some additional coagulation defects or genetic factors (14). In the present case, though we did not study all coagulation factors, only protein $\mathrm{C}$ deficiency was found as a risk factor for pulmonary thromboembolism of the patient and his father. For example, the ATIII level of the patient was normal and of his father was only $15 \%$ lower than normal range, so there was little possibility that their ATIII activity caused their pulmonary thromboembolism.

Thus, the spectrum of clinical manifestations caused by protein C deficiency is rather wide. Usually protein C deficiency is thought to be transmitted as autosomal dominant with significant variable penetrance, but individuals homozygous or compound heterozygous for protein $\mathrm{C}$ deficiency suffer from massive disseminated intravascular coagulation or fatal neonatal purpura fulminants $(15,16)$.

In heterozygous deficiency, the levels of plasma protein C are usually between $35-65 \%$ of normal level, whereas the majority of normal individuals have levels between $70-130 \%$ (10). The protein $\mathrm{C}$ deficiency members with genetic mutation in this study had protein C activities between $28-43 \%$ of the normal level, suggesting that the two affected individuals are in a heterozygous state with autosomal dominant inheritance of low penetrance with regard to thrombosis (17).

Both a quantitative and qualitative decrease in protein $\mathrm{C}$ were recognized, the former being type I deficiency and the latter, type II (18). The initial diagnosis of either form involves functional activity assay while differentiation between the two also requires an antigenic immunological assay (19). In this report, antigenic assays were also performed. Although variable, protein $\mathrm{C}$ activity of the patient was reduced to a greater extent than antigen. Protein $\mathrm{C}$ activity divided by antigen was 0.63 . Protein $\mathrm{C}$ activity of his father was also reduced to a greater extent than antigen. Protein C activity divided by the antigen was 0.5 . A ratio of protein $\mathrm{C}$ to antigen less than 0.7 suggests type II deficiency (4). Therefore, these data suggested that both the patient and his father might have type II deficiency. The patient's mother and sister had normal levels of both protein $\mathrm{C}$ activity and 


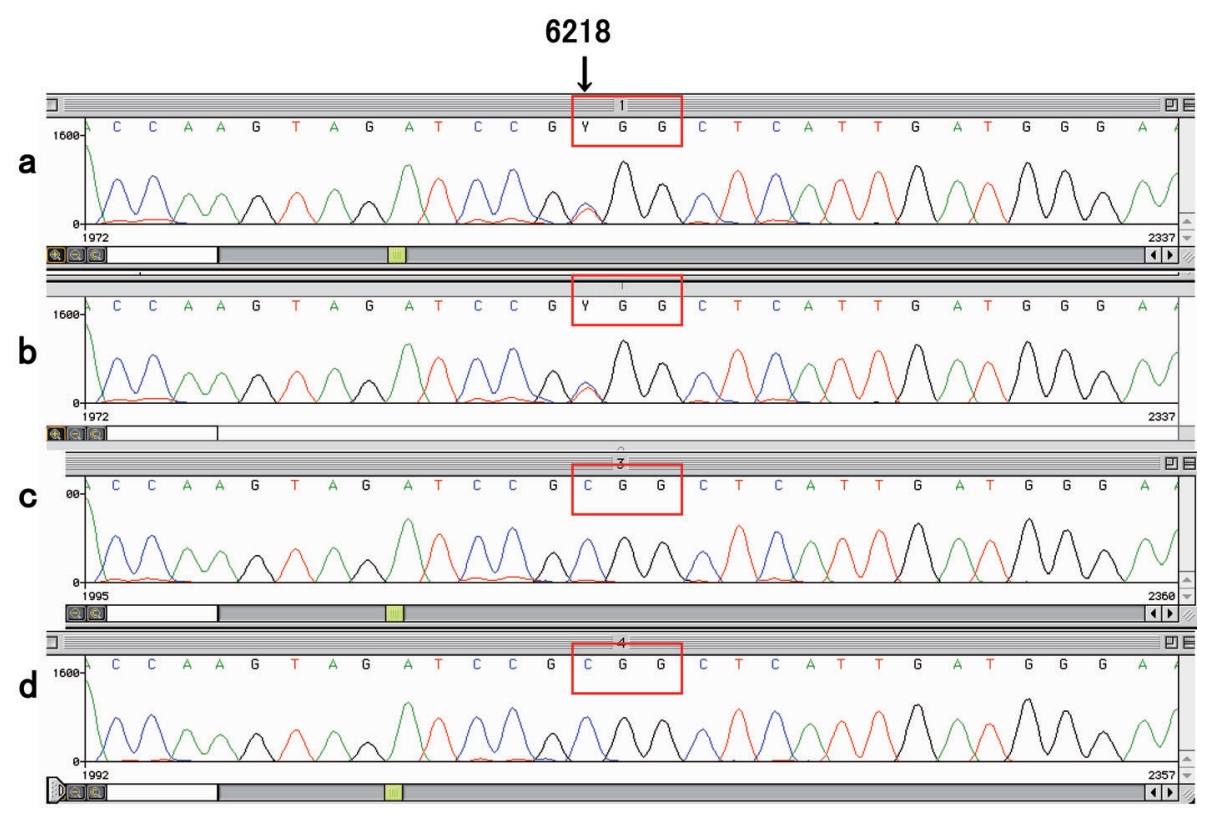

Figure 3. DNA Sequences of the exon 7 of protein C. a: the patient, b: his father, c: his mother, d: his sister. The patient, his father, and his mother have $\mathrm{C}$ to $\mathrm{T}$ change at nucleotide number 6218 (arrow) of the protein $c$ gene. This missense mutation causes that CGG coding for Argine-169 in the heavy chain to be changed to TGG coding for tryptophan.

antigen.

In this paper, we identified the same $\mathrm{C}$ to $\mathrm{T}$ change at nucleotide number 6,218 of the protein $\mathrm{C}$ gene in the patient and his father. This missense mutation caused CGG coding for arginine-169 in the heavy chain to be changed to TGG coding for tryptophan. This mutation abolishes the site of thrombin cleavage that activates protein $\mathrm{C}(20)$. However, unaffected family members without protein $\mathrm{C}$ deficiency showed the same pattern as those of normal control subjects.

The identified missense mutation in this study was previously reported. Sakata et al examined 67 Japanese families with protein $\mathrm{C}$ deficiency including the results of other studies in 10 families (21). They identified 39 different gene defects, including 29 missense mutations, 2 nonsense mutations, 4 deletions and 4 splice site mutations (Table 4). Of 29 missense mutations, 21 were type I deficiency and only 8 were type II deficiency. The identified missense mutation in this study (Arg169Trp) was previously reported in 7 Japanese families and in 10 families worldwide (mutation of a CG to either TG or CA) (Tables 4, 5) $(6,21)$. Sakata et al (21) reported that all 7 Japanese families had type I deficiency. Reitsma et al (6) reported that PC-44-009 was probably type II and PC-43-011 was type II. PC-44-009 had a same missense mutation Arg169Trp as the present case. PC43-011 had a missense mutation Arg169Gln. In the present case, the patient and his father may have type II deficiency, which is rare. 169Arg mutations are sometimes associated with type II deficiency but also with type I. The reason for the discrepancy is unknown (4). Since the C of the CG dinucleotide is frequently methylated, and subsequently deaminated, this event explains why CG dinucleotides are hotspots for mutation in the human DNA $(22,23)$.
We searched for possible causative mutations within at least 500 base pairs of promoter regions and all nine exons and exon-intron boundaries of the protein $\mathrm{C}$ gene and found three nucleotide substitutions: One was a missense mutation Arg 169Trp, and the other two were C-154T promoter polymorphism (rs1799808 on dbSNP database) and Ser99Ser synonymous polymorphism (rs5936). All three mutations were found in the patient and his father. C-154T promoter polymorphism (rs1799808 on dbSNP database) and Ser99ser synonymous polymorphism (rs5936) were found in the patient's mother. Five cis-elements were reported to regulate protein $\mathrm{C}$ expression (24). The region -88 to +45 was the main positive promoter, the region- 418 to -298 was a weak positive promoter, and the region-144 to -88 was a weak negative promoter. Two different mutations of 5'-Untranslated region were identified in Japan, which were G-1458A and A-1469C (Table 4). Eight different mutations of 5'-Untranslated region were identified in Western countries: which were A-1533 G, T-1528A, T-1515C, C-1511T, G-1480A, C93T, C-26T, and G-17C. The importance of the transition of $\mathrm{C}$ to $\mathrm{T}$ at nucleotide -154 in promoter region, which we identified is unclear. However, possible regulatory effects of promoter polymorphism on the protein $\mathrm{C}$ gene expression might affect the penetrance of individuals in heterozygous deficiency and might cause type II deficiency. If both parents had protein $\mathrm{C}$ deficiency, the child might tend to have symptomatic thrombosis, though the patients are asymptomatic (25). In the present case protein $\mathrm{C}$ activity seemed to recover in the patient compared to his father (Table 3), which might also suggest a possible role of C-154T mutation. The nucleotides of the protein $\mathrm{C}$ gene in this are numbered according to Foster et al (26). 
DOI: $10.2169 /$ internalmedicine.46.6277

Table 4. Genetic Defects of Protein C Deficiency Found in Japanese Subjects

\begin{tabular}{|c|c|c|c|}
\hline Mutation & name of Proband & $\begin{array}{l}\text { Total in } \\
\text { Japanese }\end{array}$ & Worldwide \\
\hline \multicolumn{4}{|c|}{ Missense mutations } \\
\hline $\mathrm{M}-42 \mathrm{~T}$ & Osaka 5 & 1 & none \\
\hline $\mathrm{V}-17 \mathrm{M}$ & Osaka 45 & 1 & 1 family \\
\hline $\mathrm{H}-9 \mathrm{Q}$ & Osaka 47 & 1 & none \\
\hline $\mathrm{R}-1 \mathrm{~S} *$ (II) & Osaka 10 & 1 & none \\
\hline R15G (II ) & Yonago & 1 & none \\
\hline E26K ( II ) & Mie & 1 & none \\
\hline G83R* & Osaka 14 & 1 & none \\
\hline H107P & Osaka U2 & 1 & none \\
\hline F139V & Osaka $11,19,27,29,40$ & 5 & none \\
\hline R143S & Osaka 38 & 1 & none \\
\hline \multirow[t]{2}{*}{ R169W* } & Osaka $1,31,42,43,46$ & & \\
\hline & Tochigi, Unnamed & 7 & 10 families \\
\hline R178Q* & Tokyo 1 & 1 & 6 families \\
\hline $\mathrm{H} 202 \mathrm{Y}$ & Osaka 37 & 1 & 1 family \\
\hline G282S* & Osaka 29 & 1 & 4 families \\
\hline $\mathrm{R} 286 \mathrm{H} *$ & Osaka 18,22 & 2 & 2 families \\
\hline G292S* & Nagoya 2 & 1 & 4 families \\
\hline \multirow[t]{2}{*}{ V297M* } & Osaka $17,20,24,26,30$ & & \\
\hline & 41, 48, Nara, Fukuoka & 9 & 6 families \\
\hline T298M* & Osaka 44 & 1 & 5 families \\
\hline P327L* & Osaka 6 & 1 & 2 families \\
\hline C331R & Tokyo 1 & 1 & none \\
\hline E341G & Sakaiminato & 1 & none \\
\hline G350R* (II ) & Osaka 9 & 1 & 1 family \\
\hline D359N* (II) & Osaka $7,8,37$ & 3 & 2 families \\
\hline \multirow[t]{2}{*}{ M364I } & Osaka $2,21,28,35,39$ & & \\
\hline & Kawasaki 2 & 6 & none \\
\hline F368S & Osaka 13 & 1 & none \\
\hline W380C ( II ) & Osaka 15 & 1 & none \\
\hline G385R (II) & Osaka 3 & 1 & none \\
\hline L387F (II) & Osaka 23 & 1 & none \\
\hline Y399H & Osaka 4 & 1 & none \\
\hline \multicolumn{4}{|c|}{ Nonsense mutations } \\
\hline E92stop* & Osaka 12 & 1 & 2 families \\
\hline R157stop* & Kyoto & 1 & 5 families \\
\hline \multicolumn{4}{|c|}{ Deletions and addition } \\
\hline K150del & Osaka 36, 39, Kitakyushu & 3 & none \\
\hline D255del & Osaka 16 & 1 & none \\
\hline \multirow[t]{2}{*}{ G8857del } & Osaka 25, Tokyo 2, Nagoya 1 & & \\
\hline & Mie, Kawasaki 2, Tsuruoka & 6 & none \\
\hline G7246add & Kawasaki 1 & 1 & none \\
\hline \multicolumn{4}{|l|}{ Splice site } \\
\hline G3079A & Osaka 32, Osaka U1 & 2 & none \\
\hline G3218C & Osaka 49 & 1 & none \\
\hline \multicolumn{4}{|c|}{$5^{\prime}$-untranslated region } \\
\hline G-1458A & Osaka 33 & 1 & none \\
\hline A-1469C & Osaka 34 & 1 & none \\
\hline Families & & 67 & \\
\hline Defects & & 39 & \\
\hline
\end{tabular}

*: mutation of a CG to either TG or GA, (II): type II mutation 
Table 5. Genetic Defects of Protein C Deficiency Found in Subjects Worldwide

\begin{tabular}{lcclll}
\hline \multicolumn{1}{c}{ Pedigree } & $\begin{array}{l}\text { Antigen } \\
\text { (\% of normal) }\end{array}$ & $\begin{array}{l}\text { Activity } \\
\text { (\% of normal) }\end{array}$ & $\begin{array}{l}\text { Nucleotide } \\
\text { position and } \\
\text { mutation }\end{array}$ & $\begin{array}{l}\text { Amino acid } \\
\text { change }\end{array}$ & $\begin{array}{l}\text { Co } \\
\text { segregation }\end{array}$ \\
\hline PC-49-010 & 31 & 29 & $6218 \mathrm{C} \rightarrow \mathrm{T}$ & $169 ; \mathrm{R} \rightarrow \mathrm{W}$ & 5 \\
PC-39-I-013 & 25 & 15 & $6218 \mathrm{C} \rightarrow \mathrm{T}$ & $169 ; \mathrm{R} \rightarrow \mathrm{W}$ & 4 \\
PC-39-I-041 & 84 & 48 & $6218 \mathrm{C} \rightarrow \mathrm{T}$ & $169 ; \mathrm{R} \rightarrow \mathrm{W}$ & \\
PC-81-Tochigi & 19 & $<1$ & $6218 \mathrm{C} \rightarrow \mathrm{T}$ & $169 ; \mathrm{R} \rightarrow \mathrm{W}$ & \\
PC-81-Osaka 1 & 60 & 49 & $6218 \mathrm{C} \rightarrow \mathrm{T}$ & $169 ; \mathrm{R} \rightarrow \mathrm{W}$ & 2 \\
PC-I-Unnamed & 52 & 50 & $6218 \mathrm{C} \rightarrow \mathrm{T}$ & $169 ; \mathrm{R} \rightarrow \mathrm{W}$ & 2 \\
PC-44-009 & 40 & 30 & $6218 \mathrm{C} \rightarrow \mathrm{T}$ & $169 ; \mathrm{R} \rightarrow \mathrm{W}$ & 3 \\
PC-43-011 & 36 & 23 & $6219 \mathrm{G} \rightarrow \mathrm{A}$ & $169 ; \mathrm{R} \rightarrow \mathrm{Q}$ & 2 \\
PC-31-LETS104 & & 47 & $6219 \mathrm{G} \rightarrow \mathrm{A}$ & $169 ; \mathrm{R} \rightarrow \mathrm{Q}$ & \\
PC-31-LETS623 & & 59 & $6219 \mathrm{G} \rightarrow \mathrm{A}$ & $169 ; \mathrm{R} \rightarrow \mathrm{Q}$ & \\
\hline
\end{tabular}

After treatment with heparin, followed by oral anticoagulant (warfarin potassium), deep vein angiography of the patient disclosed no thrombosis of the femoral veins of the right leg (data not shown). Also deep vein angiography of his father disclosed no thrombosis of the femoral veins of both legs (data not shown). Both of them had no episodes of spending many hours per day in a predominantly seated position (27), so the trigger of pulmonary thromboembolism was unclear.

In summary, we studied the molecular basis of protein $\mathrm{C}$ deficiency in the Japanese family of this patient with pulmonary thromboembolism. His father had been given a diagnosis of pulmonary thromboembolism. If the patient had had a chance to examine his protein $\mathrm{C}$ activity and antigen, lifestyle-related counseling might have been provided to him. Therefore if there is a possibility of protein $\mathrm{C}$ deficiency in children, screening of the parents, careful monitoring of pregnancy and occasional antenatal diagnosis should be performed. Further studies on the genetic analysis of hereditary protein $\mathrm{C}$ deficiency are required in the Japanese population and we hope that this case will be a useful model for these studies.

The authors are indebted to Prof. J. Patrick Barron of the International Medical Communications Center of Tokyo Medical University for his review of this manuscript.

\section{References}

1. Stenflo J. A new vitamin K-dependent protein. Purification from bovine plasma and preliminary characterization. J Biol Chem 251: 355-363, 1976.

2. Broekmans AW, Veltkamp JJ, Bertina RM. Congenital protein C deficiency and venous thromboembolism. A study of three Dutch families. N Engl J Med 309: 340-344, 1983.

3. Soria J, Soria C, Samama M, Nicolas G, Kisiel W. Severe protein $\mathrm{C}$ deficiency in congenital thrombotic disease-description of a immunoenzymological assay for protein $\mathrm{C}$ determination. Thromb Haemost 53: 293-296, 1985.

4. Reitsma PH. Protein C deficiency: from gene defects to disease. Thromb Haemost 78: 344-350, 1997.

5. Plutzky J, Hoskins JA, Long GL, Crabtree GR. Evolution and organization of the human protein $\mathrm{C}$ gene. Proc Natl Acad Sci USA 83: 546-550, 1986.

6. Reitsma PH, Bernardi F, Doig RG, et al. Protein C deficiency: a database of mutations, 1995 update. Thromb Haemost 73: 876889, 1995.

7. Hayashi T, Suzuki K, Protein C. Nippon Rinsho 53 Suppl: 112116, 1995 (in Japanese).

8. Hayashi T, Suzuki K, Protein S. Nippon Rinsho 53 Suppl: 117121, 1995 (in Japanese).

9. Griffin JH, Evatt B, Zimmerman TS, Kleiss AJ, Wideman C. Deficiency of protein $\mathrm{C}$ in congenital thrombotic disease. J Clin Invest 68: 1370-1373, 1981.

10. Marlar RA, Mastovich S. Hereditary protein C deficiency: a review of the genetics, clinical presentation, diagnosis and treat- ment. Blood Coagul Fibrinolysis 1: 319-330, 1990.

11. Miletich J, Sherman I, Broze G Jr. Absense of thrombosis in subjects with heterozygous protein $\mathrm{C}$ deficiency. N Engl J Med 317: 991-996, 1987.

12. Bovill EG, Bauer KA, Dickerman JD, Callas P, West B. The clinical spectrum of heterozygous protein $\mathrm{C}$ deficiency in a large New England kindred. Blood 73: 712-717, 1989.

13. Formstone CJ, Hallam PJ, Tuddenham EG, et al. Severe perinatal thrombosis in double and triple heterozygous offspring of a family segregating two independent protein $\mathrm{S}$ mutations and a protein $\mathrm{C}$ mutation. Blood 87: 3731-3737, 1996.

14. Ohwada A, Takahashi H, Uchida K, Nukiwa T, Kira S. Gene analysis of heterozygous protein $\mathrm{C}$ deficiency in a patient with pulmonary arterial thromboembolism. Am Rev Respir Dis 145: 1491-1494, 1992.

15. Yamamoto K, Matsushita T, Sugiura I, et al. Homozygous protein $\mathrm{C}$ deficiency: identification of a novel missense mutation that causes impaired secretion of the mutant protein C. J Lab Clin Med 119: 682-689, 1992.

16. Seligsohn U, Berger A, Abend M, et al. Homozygous protein C deficiency manifested by massive venous thrombosis in the newborn. N Engl J Med 310: 559-562, 1984.

17. Long GL, Tomczak JA, Rainville IR, Dreyfus M, Schramm W, Schwarz HP. Homozygous type I protein C deficiency in two unrelated families exhibiting thrombophilia related to Ala136 $\rightarrow$ Pro or Arg286 $\rightarrow$ His mutations. Thromb Haemost 72: 526-533, 1994.

18. Berdeaux DH, Abshire TC, Marlar RA. Dysfunctional protein C 
deficiency (type II). A report of 11 cases in 3 American families and review of the literature. Am J Clin Pathol 99: 677-686, 1993.

19. Marchetti G, Patracchini P, Gemmati D, et al. Symptomatic type II protein C deficiency caused by a missense mutation (Gly381 $\rightarrow$ Ser) in the substrate-binding pocket. Br J Haematol 84: 285-289, 1993.

20. Esmon CT, Protein C: biochemistry, physiology, and clinical implications. Blood 62: 1155-1158, 1983.

21. Sakata T, Kario K, Katayama Y, et al. Studies on congenital protein $\mathrm{C}$ deficiency in Japanese: Prevalence, Genetic Analysis, and Relevance to the onset of arterial occlusive diseases. Semin Thrombo Hemostasis 26: 11-16, 2000.

22. Barker D, Schafer M, White R. Restriction sites containing CpG show a higher frequency of polymorphism in human DNA. Cell
36: 131-138, 1984.

23. Cooper DN, Youssoufian $\mathrm{H}$. The $\mathrm{CpG}$ dinucleotide and human genetic disease. Hum Genet 78: 151-155, 1988.

24. Tsay W, Lee YM, Lee SC, Shen MC, Chen PJ. Characterization of human protein $\mathrm{C}$ gene promoter: Insights from natural human mutants. DNA Cell Biol 15: 907-919, 1996.

25. Matsuda M, Sugo T, Sakata $Y$, et al. A thrombotic state due to an abnomal protein C. N Engl J Med 319: 1265-1268, 1988.

26. Foster DC, Yoshitake S, Davie EW. The nucleotide sequence of the gene for human protein C. Proc Natl Acad Sci USA 82: 46734677, 1985.

27. Ogura T, Abe T, Takada N, et al. Chronic recurrent Pulmonary Thromboembolism Associated with Sedentary Work. Nihon Kyobu Shikkan Gakkai Zasshi 34: 194-199, 1996.

(C) 2007 The Japanese Society of Internal Medicine http://www.naika.or.jp/imindex.html 